\title{
Impact of Different Types of Organic Mulch on Growth, Yield, Soil Dynamics and Weed Infestation in Beetroot (Beta vulgaris L.cv. Detroit Dark Red) Plots
}

\section{Pinaki Acharyya ${ }^{1} *$, Anannya Banerjee ${ }^{1}$, Dipankar Mukherjee ${ }^{1}$, Joydip Mandal ${ }^{2}$ and Biswanath Sahoo $^{3}$}

${ }^{1}$ Department of Horticulture, Institute of Agricultural Science, University of Calcutta, Kolkata-700019, West Bengal, India

${ }^{2}$ Department of Horticulture and Post Harvest Technology, Institute of Agriculture, Visva-Bharati, Sriniketan - 731236, West Bengal, India

${ }^{3}$ Krishi Vigyan Kendra (Orissa University of Agriculture \& Technology), Ranital, Bhadrak-756111, Odisha, India

*Corresponding author
Keywords

Beet root, Organic mulch, Water conservation, Temperature regulation, Yield, Weed biomass

Article Info

Accepted:

14 June 2020

Available Online:

10 July 2020

\section{A B S T R A C T}

A study was conducted at the Agricultural Experimental Farm of Calcutta University at Baruipur, 24-Parganas (South), West Bengal, India, to record the impact of nine different organic mulches used during the cultivation of beet root crop, c.v. Detroit Dark Red. Sawdust, water hyacinth and unwoven jute mulch enhanced vegetative growth as well as overall yield of the crop to a satisfactory level. Soil temperature was kept moderate under water hyacinth and sawdust mulch. Low water potential values were observed under sawdust, coal ash, FYM and banana leaf mulch thus confirming better water conservation. Mango leaf mulch was more successful than rest of the mulches in arresting weed growth due to it's allelopathic nature. None of the organic mulches had an impact on qualitative traits like TSS, total sugar, ascorbic acid and antioxidant activity.

\section{Introduction}

Beetroot (Beta vulgaris L.), also called as garden beet or table beet, is one of the major root vegetable, belongs to the family
Chenopodiaceae and has chromosome number of $2 n=18$. This crop is a biennial grown as a cool season annual. It is grown in almost all states of India but in small scale only. It produces green tops and a swollen 
root used both as vegetable and salad. It is a rich source of protein, carbohydrate, calcium, phosphorous and vitamin $\mathrm{C}$ hence, an ideal vegetable for a healthy diet (Deuter and Grundy, 2004). Red colour of roots is due to presence of betanine pigment. The present investigation was aimed to evaluate the efficacy of some organic mulches on the production of beetroot which are in good demand by the local masses during the winter and thereafter. In order to meet the requirement of large supplies of nutrients in relatively short periods, especially in root vegetables, mineral fertilizers have been often used with exaggeration, thus alternatives suggesting minimizing of the chemical fertilizers in the production process is the need of the hour. Mulching favors a higher aggregation, water retention and prevention of erosion, reducing losses through leaching due to greater increment of organic matter along the years (Batista et al., 2012), thus contributing to the increase in the cation exchange capacity (CEC) of the soil and in the retention of nutrients close to its particles (Bonini et al., 2015), besides promoting improvement of soil physical and microbiological characteristics (Graham and Haynes, 2006).

In India, the agricultural sector is the prime consumer of water in which it is used mostly for irrigation purposes. The large variation in the temporal-spatial variation in rainfall observed in several regions of this country have experienced meager to severe drought. Improving the water use efficiency without increasing the cost of production is an ongoing goal in crop production system. It has become essential to adopt conservation practices to sustain the yield of the crop, mulching being one of them. The important objectives of mulching are moisture conservation, temperature control, prevention of surface compaction, weed control, reduction of runoff and erosion as well as an overall improvement in soil structure which will enhance water holding capacity, moisture conservation and improvement in soil drainage property. The technique is very useful in protecting the roots of the plants from heat and cold stress. The process also aids in temperature moderation, salinity reduction and weed control. Thus, application of this process exerts decisive effects on earliness, yield and quality of the crop. Use of organic mulches prevents soil erosion and moderate the soil temperature that assuring optimal nutrition to the plants as it slowly composts to give plants a season long feeding and checks the pathogens and pests. Several researchers have reported that mulching with straw, compost, leaves, newspapers etc. increases water retention and prevents soil evaporation.

Keeping in mind the enormous potentialities of the vegetable root crops and the role of organic mulches in sustaining the yield, an experimental setup was framed for studying morphological and yield related characters of beet root raised under different organic mulching material and variation in the major qualitative traits under different sets of mulching. Biomass of the weed in terms of dry weight gathered from the mulched plots was worked out towards weed suppression by different organic mulches. Average temperature of the soil under different mulch materials and its linkage to water conservation in the crops under study were also recorded during the course of investigation.

\section{Materials and Methods}

The experiment was conducted at Agricultural Experimental Farm of Calcutta University at Baruipur, 24-Parganas (South) [88 28` East longitude, 22 North latitude] during winter to early summer of 2017-2018 and 20182019.Topography of the land was uniform with medium fertility 
and clay loam texture. The experiment was laid out in a randomized block design having two replicates. Beet root variety cv. Detroit Dark Red was utilized. The seeds were sown at a spacing of $15 \times 20 \mathrm{~cm}$, having a population of thirty plants per plot. Five healthy plants were selected randomly for record of experimental data. The selected plants were subjected to observation pertaining to germination parameters, morphological feature, and yield attributing characters as well as estimation of some qualitative parameters. Besides, hydrothermal regime and weed count in each of the treatment plots were carried out to get a subtle inference. Different organic mulches used during the study and the related treatment details for the experimental setup is presented in Table 1.

Growth and developmental characters included germination percentage, days to first germination and seedling vigour index. Morphological traits included average number of leaves per plant, leaf length, leaf width, leaf area, shoot length, root length and root diameter Yield and yield related traits include fresh and dry weight of root as well as yield per plot. Number of days to edible maturity was also noted.

Qualitative trats included estimation of ascorbic acid content of the fruits by the titrimetric method as described by Rangana (1986), Total soluble solids (TSS) of extracted beet root juice with the help of Erma hand refractometer (0 to $32 \%$ range), total sugar in percentage(Ranganna,1994), Radical scavenging activity was also estimated using the DPPH assay. It was based on the measurement of scavenging ability of antioxidants towards the stable DPPH radical (Brand Williams et al., 1995). Change in absorbance of the sample extract was measured at $517 \mathrm{~nm}$. Antioxidant activity of extract was determined based on the inhibition of DPPH absorbance by calculating percentage of antioxidant activity.

Platinum resistance thermometers were installed between rows in centre of one replication of each treatment at $5,10 \mathrm{~cm}$ depth to measure the soil temperatures. The temperatures in ${ }^{\circ} \mathrm{C}$ were recorded daily for minimum at $07.30 \mathrm{hrs}$ and maximum at 2.30 hrs. Data on weed count were collected from each net plot of all replicates. For weed count half square meter area $(50 \times 50 \mathrm{~cm})$ was fixed randomly before emergence of weeds. Biomass of weeds growing within the area was weighed after 60 days of sowing.

\section{Results and Discussion}

\section{Physicochemical analysis of soil}

The apparent density of the soil was $1.24 \mathrm{gm} / \mathrm{cc}$. Absolute specific gravity of the soil was 2.56 while maximum water holding capacity of the soil was $53.80 \%$. The $\mathrm{pH}$ of the soil was 6.4 tending to be slightly acidic and EC of the soil was $0.13 \mathrm{ds} / \mathrm{m}$. Organic carbon content of the soil is $1.02 \%$. The total nitrogen content of the soil was $0.18 \%$ while available phosphorous was $30 \mathrm{~kg} / \mathrm{ha}$. Available nitrogen recorded for the soil was $0.07 \%$ and available potassium recorded was $260 \mathrm{~kg} / \mathrm{ha}$. The CEC observed for the soil was $27.00 \mathrm{~m} . \mathrm{e} / 100 \mathrm{gm}$ of soil.

\section{Germination related parameters}

Germination related parameters have been highlighted in Table 2 . The germination related parameters like germination percentage as well as the seed vigour index was found to be high under sawdust mulch $(29.99 ; 2627.12)$ respectively. It was followed by water hyacinth mulch and unwoven jute mulch. Unmulched plots resulted in low germination percentage and seedling vigor index. With respect to days to first 
germination, it was revealed that seedlings in unwoven jute mulch was the earliest (9.00) followed by FYM mulch (9.10). Heydecker and Chetram (1970) while working on water relations of germination of beetroot seed observed that conditions in which seeds of beetroot (Beta vulgaris L.) will germinate are relatively narrowly limited by a deficient or an excessive water-supply. The ovary cap, which covers each seed situated within its locule in the seed cluster, has been shown to be responsible, under wet conditions, for preventing access of oxygen to the embryo owing to its imperviousness to gas and to the production of mucilage around its rim in the presence of excess water. Removal of the ovary cap enables seeds to germinate even under water. Our investigation shows that saw dust exhibited higher percentage of germination which may have successfully removed the ovary cap due to its acidic action. Further, it may have neutralized the endogenous water-soluble germination inhibitor complex. Some of the treatments like those under unmulched situation, banana leaves and newspaper realized depressed germination which may be correlated to restricted oxygen uptake of the imbibing seeds due to slow dislodging of the ovary cap.

\section{Morphological traits}

The observations pertaining to the below mentioned morphological traits are depicted in Table 3.In beet root, the average number of leaves was high in sawdust (10.90) followed by unwoven jute(10.10). Both leaf length (28.00) as well as leaf width (8.60) was high under saw dust mulch. The maximum leaf area was also high in sawdust mulch $(125.65 \mathrm{sq} \mathrm{cm})$ followed by water hyacinth mulch $(108.77 \mathrm{sq} \mathrm{cm})$. In a similar manner, average shoot length was also high under saw dust mulch $(29.30 \mathrm{~cm})$ followed closely by water hyacinth mulch $(28.20 \mathrm{~cm})$ and unwoven jute mulch $(26.60 \mathrm{~cm})$. FYM mulch also supported the vegetative growth in a robust manner. Regarding the root features, maximum root length was observed in water hyacinth mulch $(14.80 \mathrm{~cm})$ followed by saw dust $(14.70 \mathrm{~cm})$ and unwoven jute mulch $(11.30 \mathrm{~cm})$. The average root diameter was maximum under sawdust $(48.86 \mathrm{~cm})$ followed by water hyacinth $(45.80 \mathrm{~cm})$. Unmulched plots had the least root length and diameter. It seemed that interactions between sawdust and the added fertilizer during sowing helped to establish satisfactory conditions for decomposition of sawdust without reducing available nutrients to a crop. Adding sufficient nitrogen and phosphorus to sawdust at time of its incorporation to bring it to a critical nitrogen percentage (Allison and Anderson, 1951) is not sufficient, but rather must be maintained during the five to six years of decomposition. Besides, the microbial activity associated with sawdust, leaching and/or excessive moisture accompanied by de-nitrification also plays an important role in enriching the soil strata. It may be suggested that growing beet root under sawdust, water hyacinth and unwoven jute mulch leads to enhanced vegetative growth which invariably increases the yield potential.

\section{Yield and yield related traits}

The observations pertaining to the below mentioned yield and yield related traits are depicted in Table 3. All the related observations were statistically significant. Yield and yield related traits pertaining to fresh and dry weight of the roots and yield per plot also depicted sawdust mulch as the front runner having an average plot yield of $1139.05 \mathrm{~g}$.It was closely followed by water hyacinth and unwoven jute mulch. In days to edible maturity, earliness was noted in water hyacinth closely followed by FYM mulch. All the aforesaid mulches are beneficial for beet root crop as they had fairly good vegetative 
growth. Both unmulched plots and banana mulch were poor yielders, the influence of the hot weather on conditions of bare soil led to lower yield compared with mulched plots. Moreover there has been a strong competition between weeds and crops for growth factors.

Table.1 Treatment details regarding use of different organic mulch

\begin{tabular}{|c|c|}
\hline Treatment & Mulch material \\
\hline $\mathbf{T}_{\mathbf{1}}$ & Farm yard manure \\
\hline $\mathbf{T}_{\mathbf{2}}$ & Saw dust \\
\hline $\mathbf{T}_{\mathbf{3}}$ & Banana leaves \\
\hline $\mathbf{T}_{\mathbf{4}}$ & Chopped water hyacinth \\
\hline $\mathbf{T}_{\mathbf{5}}$ & Jute non oven \\
\hline $\mathbf{T}_{\mathbf{6}}$ & Shredded News paper \\
\hline $\mathbf{T}_{\mathbf{7}}$ & Rice straw \\
\hline $\mathbf{T}_{\mathbf{8}}$ & Coal Ash \\
\hline $\mathbf{T}_{\mathbf{9}}$ & Mango leaves \\
\hline $\mathbf{T}_{\mathbf{1 0}}$ & Control \\
\hline
\end{tabular}

Table.2 Effect of different mulch materials on germination parameters of Beet root cv. Detroit Dark Red

\begin{tabular}{|c|c|c|c|}
\hline Treatments & $\begin{array}{c}\text { Average } \\
\text { Germination }\end{array}$ & $\begin{array}{c}\text { Days to } \mathbf{1}^{\text {st }} \\
\text { germination }\end{array}$ & Seedling Vigour Index \\
\hline $\mathbf{T}_{\mathbf{1}}$ & 22.23 & 9.10 & 1078.11 \\
\hline $\mathbf{T}_{\mathbf{2}}$ & 29.99 & 24.50 & 2627.12 \\
\hline $\mathbf{T}_{\mathbf{3}}$ & 14.13 & 11.00 & 449.87 \\
\hline $\mathbf{T}_{\mathbf{4}}$ & 25.51 & 24.50 & 1331.84 \\
\hline $\mathbf{T}_{\mathbf{5}}$ & 24.48 & 9.00 & 1202.54 \\
\hline $\mathbf{T}_{\mathbf{6}}$ & 16.98 & 10.50 & 544.51 \\
\hline $\mathbf{T}_{\mathbf{7}}$ & 21.40 & 10.15 & 814.18 \\
\hline $\mathbf{T}_{\mathbf{8}}$ & 20.11 & 10.15 & 720.34 \\
\hline $\mathbf{T}_{\mathbf{9}}$ & 18.32 & 10.15 & 715.55 \\
\hline $\mathbf{T}_{\mathbf{1 0}}$ & 12.61 & 11.00 & 280.84 \\
\hline $\mathbf{C D}$ at 5\% & $9.48 \%$ & 2.16 & $5.02 \%$ \\
\hline $\mathbf{S E}(\mathbf{d})$ & 0.94 & 4.52 & 1.00 \\
\hline
\end{tabular}

Note: $T_{1}-\mathrm{FYM}, \mathrm{T}_{2^{-}}$SAW DUST, $\mathrm{T}_{3}$-BANANA LEAVES $\mathrm{T}_{4^{-}}$WATER HYACINTH $\mathrm{T}_{5^{-}}$UNOVEN JUTE

$\mathrm{T}_{6}-$ SHREDDED NEWS PAPER $\mathrm{T}_{7}$ - RICE STRAW $\mathrm{T}_{8}$-COAL ASH $\mathrm{T}_{9}$-MANGO LEAVES

$\mathrm{T}_{10^{-}}$CONTROL 
Table.3 Effect of different organic mulch materials on morphological and yield traits of beet root cv. Detroit Dark Red

\begin{tabular}{|c|c|c|c|c|c|c|c|c|c|c|c|}
\hline Treatments & $\begin{array}{c}\text { Average } \\
\text { no of } \\
\text { leaves }\end{array}$ & $\begin{array}{c}\text { Average } \\
\text { Leaf } \\
\text { length }(\mathrm{cm})\end{array}$ & $\begin{array}{l}\text { Average } \\
\text { Leaf } \\
\text { width } \\
(\mathrm{cm})\end{array}$ & $\begin{array}{l}\text { Average } \\
\text { Leaf } \\
\text { area } \\
(\mathrm{cm})\end{array}$ & $\begin{array}{c}\text { Average } \\
\text { shoot } \\
\text { length }(\mathrm{cm})\end{array}$ & $\begin{array}{l}\text { Average } \\
\text { root } \\
\text { length } \\
(\mathrm{cm})\end{array}$ & $\begin{array}{c}\text { Root } \\
\text { diameter } \\
(\mathbf{m m})\end{array}$ & $\begin{array}{c}\text { Root } \\
\text { fresh } \\
\text { weight } \\
\text { (g) }\end{array}$ & $\begin{array}{c}\text { Root } \\
\text { dry } \\
\text { weight } \\
\text { (g) }\end{array}$ & $\begin{array}{c}\text { Yield } \\
\text { per plot } \\
(\mathrm{g})\end{array}$ & $\begin{array}{l}\text { No of days } \\
\text { to edible } \\
\text { maturity }\end{array}$ \\
\hline$T_{1}$ & 10.05 & 23.90 & 6.40 & 90.50 & 25.00 & 11.10 & 40.93 & 226.49 & 48.13 & 724.73 & 85.37 \\
\hline $\mathbf{T}_{2}$ & 10.90 & 28.00 & 8.60 & 125.65 & 29.30 & 14.70 & 48.86 & 450.96 & 87.60 & 1139.05 & 86.70 \\
\hline$T_{3}$ & 8.70 & 18.10 & 4.35 & 49.95 & 17.20 & 7.70 & 31.46 & 122.24 & 31.68 & 283.37 & 92.38 \\
\hline $\mathbf{T}_{4}$ & 10.45 & 27.40 & 8.20 & 108.77 & 28.20 & 14.80 & 45.80 & 381.28 & 50.34 & 951.12 & 72.57 \\
\hline$T_{5}$ & 10.10 & 26.20 & 8.50 & 107.63 & 26.60 & 11.30 & 42.60 & 360.01 & 50.02 & 747.39 & 88.32 \\
\hline$T_{6}$ & 7.95 & 18.40 & 5.45 & 83.80 & 18.60 & 9.90 & 32.96 & 171.10 & 33.20 & 450.77 & 85.62 \\
\hline $\mathbf{T}_{7}$ & 9.60 & 22.40 & 7.65 & 87.55 & 23.20 & 10.60 & 40.93 & 206.24 & 40.87 & 491.30 & 90.73 \\
\hline $\mathbf{T}_{8}$ & 8.95 & 21.20 & 7.25 & 75.08 & 22.20 & 10.20 & 35.80 & 156.99 & 37.53 & 393.92 & 90.35 \\
\hline $\mathbf{T}_{9}$ & 9.10 & 19.60 & 5.40 & 44.72 & 19.00 & 10.10 & 33.46 & 176.32 & 36.11 & 314.95 & 93.22 \\
\hline $\mathbf{T}_{10}$ & 6.95 & 17.00 & 4.32 & 49.18 & 16.80 & 5.50 & 27.53 & 85.49 & 27.11 & 225.11 & 93.31 \\
\hline CD at $5 \%$ & 0.81 & 1.54 & 4.53 & 9.70 & 0.97 & 7.68 & 3.05 & $8.02 \%$ & $4.40 \%$ & $7.38 \%$ & $4.07 \%$ \\
\hline SE(d) & 1.69 & 3.22 & 0.98 & 0.96 & 4.86 & 0.96 & 0.99 & 0.99 & 0.99 & 0.99 & 0.88 \\
\hline
\end{tabular}

Note: $\mathrm{T}_{1^{-}} \mathrm{FYM}, \mathrm{T}_{2^{-}} \mathrm{SAW}$ DUST $\quad \mathrm{T}_{3^{-}}$BANANA LEAVES $\mathrm{T}_{4^{-}}$WATER HYACINTH $\mathrm{T}_{5^{-}}$UNOVEN

JUTE $T_{6}-$ SHREDDED NEWS PAPER $T_{7}$-RICE STRAW $T_{8^{-}}$COAL ASH $T_{9^{-}}$MANGO LEAVES $T_{10^{-}}$

CONTROL

Table.4 Effect of different organic mulch materials on average soil temperature, soil water potential and weed population in plots of beet root cv. Detroit Dark Red

\begin{tabular}{|c|c|c|c|}
\hline Treatments & $\begin{array}{c}\text { Average soil } \\
\left.\text { temperature (in }{ }^{\mathbf{0}} \mathrm{C}\right)\end{array}$ & $\begin{array}{c}\text { Soil water } \\
\text { potential }\left(\psi_{m}\right)\end{array}$ & Weed content $(\mathrm{g})$ \\
\hline $\mathbf{T}_{1}$ & 30.05 & 115.00 & 200.00 \\
\hline $\mathbf{T}_{2}$ & 23.15 & 110.00 & 171.66 \\
\hline $\mathbf{T}_{\mathbf{3}}$ & 24.65 & 115.00 & 112.46 \\
\hline $\mathbf{T}_{4}$ & 19.80 & 375.00 & 81.00 \\
\hline$T_{5}$ & 21.00 & 145.00 & 71.33 \\
\hline$T_{6}$ & 27.80 & 205.00 & 59.33 \\
\hline $\mathbf{T}_{7}$ & 23.25 & 125.00 & 53.73 \\
\hline$T_{8}$ & 20.85 & 105.00 & 68.43 \\
\hline $\mathbf{T}_{9}$ & 29.30 & 140.00 & 48.33 \\
\hline$T_{10}$ & 31.45 & 205.00 & 45.06 \\
\hline CD at $5 \%$ & $5.18 \%$ & 0.85 & $7.86 \%$ \\
\hline $\operatorname{SE}(d)$ & 0.95 & 32.95 & 0.99 \\
\hline
\end{tabular}

Note: $T_{1}-$ FYM , $T_{2}$ - SAW DUST $\quad T_{3^{-}}$BANANA LEAVES $T_{4^{-}}$WATER HYACINTH $T_{5^{-}}$UNOVEN JUTE $\mathrm{T}_{6}$ - 
Table.5 Effect of different organic mulch materials on qualitative traits in beet root cv. Detroit Dark Red

\begin{tabular}{|c|c|c|c|c|}
\hline Treatments & $\begin{array}{c}\text { Total soluble } \\
\text { solids( in } \mathbf{~} \mathbf{B})\end{array}$ & $\begin{array}{c}\text { Ascorbic acid } \\
\text { content }(\mathbf{m g} / \mathbf{g})\end{array}$ & $\begin{array}{c}\text { Antioxidant } \\
\text { activity (\%) }\end{array}$ & Total sugar(\%) \\
\hline $\mathbf{T}_{\mathbf{1}}$ & 10.50 & 10.35 & 51.37 & 3.35 \\
\hline $\mathbf{T}_{\mathbf{2}}$ & 11.00 & 5.20 & 59.36 & 11.25 \\
\hline $\mathbf{T}_{\mathbf{3}}$ & 13.50 & 6.70 & 63.32 & 8.76 \\
\hline $\mathbf{T}_{\mathbf{4}}$ & 10.50 & 6.40 & 60.52 & 5.20 \\
\hline $\mathbf{T}_{\mathbf{5}}$ & 13.00 & 5.80 & 77.91 & 6.25 \\
\hline $\mathbf{T}_{\mathbf{6}}$ & 10.00 & 9.60 & 66.88 & 8.30 \\
\hline $\mathbf{T}_{\mathbf{7}}$ & 10.95 & 4.50 & 59.16 & 11.42 \\
\hline $\mathbf{T}_{\mathbf{8}}$ & 8.50 & 8.40 & 62.38 & 6.43 \\
\hline $\mathbf{T}_{\mathbf{9}}$ & 12.50 & 6.00 & 58.23 & 8.57 \\
\hline $\mathbf{T}_{\mathbf{1 0}}$ & 9.50 & 3.50 & 56.29 & 6.0 \\
\hline $\mathbf{C D} \mathbf{a t} \mathbf{5} \%$ & $8.57 \%$ & $11.70 \%$ & $4.02 \%$ & 0.87 \\
\hline $\mathbf{S E}(\mathbf{d})$ & 0.85 & 0.94 & 0.95 & 22.83 \\
\hline
\end{tabular}

SHREDDED NEWS PAPER $\mathrm{T}_{7^{-}}$RICE STRAW $\mathrm{T}_{8^{-}}$COAL ASH $\mathrm{T}_{9}$-MANGO LEAVES $\mathrm{T}_{10^{-}}$CONTROL

Note: $T_{1^{-}}$FYM , $T_{2^{-}}$SAW DUST $\quad T_{3^{-}} \quad$ BANANA LEAVES $\quad T_{4^{-}}$WATER HYACINTH $T_{5^{-}}$UNOVEN JUTE $T_{6}$ -

\section{Hydrothermal regime}

The figures are reflected in Table 4. The average soil temperature in different treatments varied in between 19.80 to $31.45^{\circ} \mathrm{C}$. The minimum average soil temperature was noted under water hyacinth which was $19.80^{\circ} \mathrm{C}$. The maximum average soil temperature was observed in treatment $\mathrm{T}_{10} \quad\left(31.45^{\circ} \mathrm{C}\right)$. Treatments $\mathrm{T}_{2}\left(23.15{ }^{\circ} \mathrm{C}\right)$, $\mathrm{T}_{3}\left(24.65{ }^{\circ} \mathrm{C}\right), \mathrm{T}_{5}\left(21.00{ }^{\circ} \mathrm{C}\right), \mathrm{T}_{7}\left(23.25{ }^{\circ} \mathrm{C}\right)$ and $\mathrm{T}_{8}\left(20.85^{\circ} \mathrm{C}\right)$ also exhibited moderate thermal regimes. Significant differences were observed among the treatments. Tensiometer readings taken in the beet root plots under different treatments suggest that high soil water potential was observed in water hyacinth covered mulches $\left(375.00 \psi_{\mathrm{m}}\right)$ while the least was observed in ash layered mulch $\left(105.00 \psi_{\mathrm{m}}\right)$. Rest of the treatments showed low water potential ranging within 100 to $200 \psi_{\mathrm{m}}$. Control exhibited a soil water potential of $205.00 \psi_{\mathrm{m}}$ which was at par with $\mathrm{T}_{6} \quad\left(205.00 \psi_{\mathrm{m}}\right) . \quad$ Statistical significant differences existed among the treatments. high water potential was observed under hyacinth mulch $\left(375.00 \psi_{\mathrm{m}}\right)$. Saw dust, ash, FYM, banana leaves showed lower values, thus confirming better water preservation in the long run.

\section{Average weed population per plot}

The generated figures are presented in Table 4. The average weed population in different treatments varied in between 45.06 to 200 . The minimum average weed population per plot was noted in control which was 45.06 followed by mango leaves (48.33g) and paddy straw $(53.73 \mathrm{~g})$. The maximum average weed population per plot was found under FYM mulch which was 200g. Significant differences were found among the treatments. Barring the control, we may say that mango leaf mulch was more successful than rest of the mulches in arresting weed growth due to it's allelopathic nature.

\section{Qualitative attributes}

Selected qualitative traits were estimated, the values of which are presented in Table 5. The 
average total soluble solids in different treatments varied from 8.50 to $13.50^{\circ} \mathrm{B}$. Significant variation with respect to this trait was observed among the treatments. TSS was noted to be high in beet root growing under banana mulch $\left(13.50^{\circ} \mathrm{B}\right)$ followed by unwoven jute $\left(13.00^{\circ} \mathrm{B}\right)$ and mango leaves $\left(12.50^{\circ} \mathrm{B}\right)$.Highest ascorbic acid was noted under FYM mulch $(10.35 \mathrm{mg} / \mathrm{g})$ followed by newspaper mulch $(9.60 \mathrm{mg} / \mathrm{g}) . \mathrm{High}$ antioxidant activity was recorded in unwoven jute mulch $(77.91 \%)$ followed by newspaper mulch(66.68\%).Beet roots under both paddy straw and saw dust had the highest total sugar content $(11.42 \%$ and $11.25 \%)$ respectively. None of the mulch treatments had an outstanding impact on all the qualitative traits.

From our findings we can ascertain that organic mulches overall increase the crop growth of beet root though the the type of mulch to be selected rests on the environmental situation at the particular site.Further investigations are needed in confirming the quality of the produce.The only negative side is the chance of disease build up as they decay over time and provides a substrate for the inoculums. Site specific advisory with respect to organic mulches should be encouraged and mobilized at farmers level through government institutions, local bodies and academic institutions working at tandem.

\section{References}

Allison FE and Anderson M S. 1951. Use of sawdust for mulches and soil improvement. United States Department of Agriculture Circular 891.

Batista MAV, Vieira LA, Souza JP, Freitas JDB and Bezerra Neto F.2012. Efeito de diferentes fontes de adubaacosobre a producáo dealface no municipio de
Iguatu- CE. Revista Caatinga, 25: 8-11. Bonini CSB, Alves $\mathrm{MC}$ and Montanari, R.2015. Lodo de esgoto e aduba,cão mineralnarecuperac̃ao de atributosquimicos de solo degradado. Revista Brasileira de Engenharia Agricola e Ambiental, 19: 388-393.

http:// dx.doi.org/10.1590/18071929/agriambi.v19n4p388-393.

Deuter P and Grundy T. 2004. Beetroot commercial production and processing. Agency for Food and Fibre Sciences. Holland Horticultural Limited Partnership, p.1-4.

Graham MH and Haines RJ.2005. Organic matter status and the size,activity and metabolic diversity of the soil microbial community in the row and inter-row of sugarcane under a burning trash retention. Soil Biology and Biochemistry,38:21-31. http://dx.doi.org/10.1016/j.soilbio.2005. 04.011

Heydecker W and Chetram RS.1971. Water Relations of Beetroot Seed Germination: I. Microbial Factors, with Special Reference to Laboratory Germination. Annals of Botany, 35(1): 17-29.

Ranganna S.1994. Manual of Analysis of Fruit and Vegetable Products. Tata McGraw-Hill Publishing Company Limited, New Delhi. p. 634.

Ranganna S. 2000.Pectin analysis. In Handbook of Analysis of Quality control for Fruit and Vegetables Products. $2^{\text {nd }}$ ed. Tata McGraw Hill Pub. Co. New Delhi.

Williams Brand W, Cuvelier ME and Berset CLWT. 1995. Use of a free radical method to evaluate antioxidant activity. LWT-Food science and Technology, 28(1): 25-30. 


\section{How to cite this article:}

Pinaki Acharyya, Anannya Banerjee, Dipankar Mukherjee, Joydip Mandal and Biswanath Sahoo. 2020. Impact of Different Types of Organic Mulch on Growth, Yield, Soil Dynamics and Weed Infestation in Beetroot (Beta vulgaris L. cv. Detroit Dark Red) Plots. Int.J.Curr.Microbiol.App.Sci. 9(07): 1419-1427. doi: https://doi.org/10.20546/ijcmas.2020.907.163 